\title{
Editorial for the Special Issue "Platinum-Group Minerals: New Results and Advances in PGE Mineralogy in Various Ni-Cu-Cr-PGE Ore Systems"
}

\author{
Andrei Y. Barkov ${ }^{1}$ and Federica Zaccarini ${ }^{2, *}$ \\ 1 Research Laboratory of Industrial and Ore Mineralogy, Cherepovets State University, 5 Lunacharsky Avenue, \\ 162600 Cherepovets, Russia; ore-minerals@mail.ru \\ 2 Department of Applied Geological Sciences and Geophysics, University of Leoben, Peter Tunner Str. 5, \\ A-8700 Leoben, Austria \\ * Correspondence: federica.zaccarini@unileoben.ac.at
}

Received: 10 June 2019; Accepted: 11 June 2019; Published: 17 June 2019

The platinum-group minerals (PGM) consist of a group of accessory minerals that concentrate the six platinum-group elements (PGE): osmium (Os), iridium (Ir), ruthenium $(\mathrm{Ru})$, rhodium $(\mathrm{Rh})$, platinum $(\mathrm{Pt})$, and palladium (Pd). Recently, the PGE have gained tremendous importance due to their application in many modern and advanced technologies. However, with a concentration of about $10^{-6}$ to $10^{-7} \%$ in the Earth's crust, the PGE are numbered among the ultratrace elements. The PGM occur naturally, as alloys, native elements, or combinations with other elements, mainly S, As, Te, Bi, Sb, Se, and, rarely, $\mathrm{O}$. Moreover, the PGM are rare, representing only less than 3\% of the approved minerals by the Commission on New Minerals and Mineral Names of the International Mineralogical Association (IMA). Concentration of PGE of economic importance is present in mafic-ultramafic layered intrusions, in continental flood basalts, in the Alaskan-type complexes, and in the placer deposits derived by their erosion [1]. Sub-economic concentration of PGE has been reported from the organic-rich black shales of the Zechstein deposits in Poland [2] as well as from several chromitites associated with ophiolite [1]. Regarding their genesis, the PGM are divided into two main groups: 1) the primary PGM that crystallized at high temperature during the magmatic stage and 2) the secondary PGM that precipitated or have been altered and reworked at low temperature.

This Special Issue of Minerals aimed to bring together recent studies on the mineralogical aspect of the PGE with special regards on how and where the PGM formed. Occurrence and description of PGM from China, Russia, South Africa, USA, and Zimbabwe are reported.

In his contribution, Oberthür [3] reported on the presence of PGM found in the layered intrusions of the Bushveld and Great Dyke complexes, discussing in great detail, the PGM genetical evolution from their lode deposits to the placers. According to this author, the final PGM suite which survived the weathering alteration from sulfide ores via oxidized ores into placers results from the continuous elimination of unstable PGM and the dispersion of soluble PGE. The final alluvial PGM assemblage consists of a great number of residual, detrital grains accompanied by minor and rare authigenic PGM that crystallized in the supergene environment.

The study by Stepanov et al. [4] demonstrated that the degree of alteration of PGM in placers associated with the Ural-Alaskan type Svetloborsky massif is linked to the transport distance. In particular, these authors had shown that at a distance of more than $10 \mathrm{~km}$, the degree of PGM mechanical attrition becomes significant, and the primary morphological features, characteristic of lode platinum, are rarely preserved.

The origin of magmatic PGM in chromite deposits associated with ophiolites and Alaskan-type complexes of the Urals had been discussed in the paper by Zaccarini et al. [5]. Crystallization of Os, Ir, and Ru minerals in ophiolitic chromitites took place during and after primary chromite precipitation, 
under variable sulfur fugacity and temperature. The dominant PGM in the Alaskan-type chromitites are Pt-Fe alloys that crystallized at 1300 and $1050{ }^{\circ} \mathrm{C}$. On-cooling equilibration to about $900{ }^{\circ} \mathrm{C}$ may produce lamellar unmixing of different $\mathrm{Pt}-\mathrm{Fe}$ alloys and osmium. Precipitation of the Pt-Fe alloys locally is followed by an increase of sulfur fugacity leading to the formation of rare PGE sulfides.

PGM and PGE-Au phases found in alluvium along the River Bolshoy Khailyk, in the western Sayans, Russia, have been described by Barkov et al [6]. Three groups of alloy are reported and an order of crystallization is suggested: 1) Os-Ir- $\mathrm{Ru}$, 2) $\mathrm{Pt}_{3} \mathrm{Fe}$, and 3) $\mathrm{Pt}-\mathrm{Au}-\mathrm{Cu}$ alloys, which likely crystallized in the sequence from $\mathrm{Au}-(\mathrm{Cu})$-bearing platinum, $\mathrm{Pt}(\mathrm{Au}, \mathrm{Cu}), \mathrm{Pt}(\mathrm{Cu}, \mathrm{Au})$, and $\mathrm{PtAuCu}_{2}$, to $\mathrm{PtAu}_{4} \mathrm{Cu}_{5}$. Many of the Os-Ir-Ru and Pt-Fe grains have porous and altered rims that contain secondary PGM, gold, and rare Cu-rich bowieite and a Se-rich sulfarsenide of Pt. Barkov et al. [6] argued that the alloys precipitated in a highly reducing environment. Late assemblages indicate the presence of an oxygenated local environment leading to Fe-bearing Ru-Os oxide and seleniferous minerals. A primitive ultramafic rock was the source of the studied alluvial PGM and associated minerals.

A careful mineralogical study of PGM grains from alluvial placers of the Gornaya Shoria of Russia [7] allowed to postulate the conditions of their formation and alteration. The original sub-graphic and layered texture pattern of PGM and gold indicate that they are the result of solid solution and eutectic decompositions occurred at magmatic stages, including the result of the interaction of $\mathrm{Pt}_{3} \mathrm{Fe}$ with a sulfide melt enriched with Te and As.

In their review, Barkov and Cabri [8] summarized the compositional variations of major and minor elements in Pt-Fe alloys from both lode and placer occurrences found in layered intrusions, Alaskan-Uralian-(Aldan)-type and alkaline gabbroic complexes, ophiolitic chromitites from Canada, USA, Russia, and other localities worldwide. Typically, Ir, $\mathrm{Rh}, \mathrm{Pd}$, and minor $\mathrm{Cu}, \mathrm{Ni}$ are incorporated into a compositional series $(\mathrm{Pt}, \mathrm{PGE})_{2-3}(\mathrm{Fe}, \mathrm{Cu}, \mathrm{Ni})$ in the lode occurrences. In contrast, the distribution of $\mathrm{Ir}, \mathrm{Rh}$, and Pd is fairly chaotic in placer Pt-Fe grains. These authors noticed that the Pt-Fe alloys from placers are notably larger in size compared to those from lode deposits. However, based on their observation of a large dataset of Pt-Fe alloys from numerous origins, Barkov and Cabri [8] concluded that they show compositional overlaps that are too large to be useful as reliable index minerals.

Yang et al. [9] reported on the presence of PGM such as laurite, Os-Ir-Ru alloys, and minor $\mathrm{Pd}-\mathrm{Te}$, anduoite, and irarsite in dunite and chromitite of the Xiadong Alaskan-type complex located in southern Central Asia. These authors noticed that the PGM described are very different compared to the typical PGM assemblage of the Alaskan-type complexes worldwide. The highest PGE concentrations $(112 \mathrm{ppb})$ was detected in a dunite sample. Therefore, the authors suggested that the Xiadong complex has potential for PGE exploration.

The contribution by Koerber and Thakurta [10] is dealing with the investigation of a gabbro from the midcontinent rift Echo Lake intrusion in northern Michigan, USA. The authors found that the investigated rocks are characterized by a PGE-enrichment in a $45 \mathrm{~m}$ thick magnetite-ilmenite-bearing olivine gabbro unit with grades up to $1.2 \mathrm{~g} / \mathrm{t} \mathrm{Pt}+\mathrm{Pd}$ and $0.3 \mathrm{wt} \% \mathrm{Cu}$, related to the presence of disseminated pyrrhotite and chalcopyrite.

The occurrence of a rare Pt-enriched tetra-auricupride was documented by Barkov et al. [11] from an ophiolite-associated placer at Bolshoy Khailyk, western Sayans, Russia. The authors, based on the chemical composition and a synchrotron micro-Laue diffraction study, concluded that tetra-auricupride can incorporate as much as $\sim 30 \mathrm{~mol} \%$ of a " $\mathrm{PtCu}$ " component, apparently without relevant modification of the unit cell.

A mineralogical investigation of PGM nuggets composed mainly of Os-Ir-(Ru) and minor Pt-Fe alloys from the Sisim Placer, eastern Sayans, Russia, was carried out by Barkov et al. [12]. The Os-Ir-(Ru) contains several inclusions such as PGE-rich monosulfide, PGE-rich pentlandite, and Ni-Fe-(As)-rich laurite. The authors suggested that the studied nuggets derived by the erosion of a chromitite of the Lysanskiy mafic-ultramafic complex. The presence of localized fluids was recognized and the fluids were responsible for the crystallization of the unique association of laurite with monazite-(Ce) found in the Sisim Placer. 
Last but not least, this Special Issue hosts one paper in which Vymazalova et al. [13] reported the discovery of a new PGM. The new PGM, $\mathrm{Pd}_{9} \mathrm{Ag}_{2} \mathrm{Bi}_{2} \mathrm{~S}_{4}$, is named thalhammerite, and it was discovered in galena-pyrite-chalcopyrite and millerite-bornite-chalcopyrite vein-disseminated ores from the Komsomolsky mine of the Talnakh and Oktyabrsk deposits, Noril'sk region, Russia. Due to the small size of thalhammerite in the natural sample, its crystal structure was solved and refined from the single-crystal X-ray-diffraction data of synthetic $\mathrm{Pd}_{9} \mathrm{Ag}_{2} \mathrm{Bi}_{2} \mathrm{~S}_{4}$. The mineral is tetragonal, space group I4/mmm, with $a$ 8.0266(2), c 9.1531(2) $\AA, V$ 589.70(2) $\AA^{3}$, and $Z=2$.

Overall, we hope that this Special Issue will contribute to a better understanding of the origin of the PGM and will promote future investigation of tiny and rare minerals such as the PGM.

Finally, we would like to thank the authors, referees, and editorial staff of Minerals for their precious effort that contributes to the success of this Special Issue.

Author Contributions: A.B and F.Z. wrote this editorial.

Conflicts of Interest: The authors declare no conflict of interest.

\section{References}

1. Pohl, W. Economic Geology: Principles and Practice; John Wiley \& Sons: Hoboken, NJ, USA, 2011; pp. 1-680.

2. Kucha, H. Platinum-group metals in the Zechstein copper deposits, Poland. Econ. Geol. 1982, 77, 1578-1591. [CrossRef]

3. Oberthür, $\mathrm{T}$. The fate of platinum-group minerals in the exogenic environment-From sulfide ores via oxidized ores into placers: Case studies bushveld complex, South Africa, and Great Dyke, Zimbabwe. Minerals 2018, 8, 581. [CrossRef]

4. Stepanov, S.Y.; Palamarchuk, R.S.; Kozlov, A.V.; Khanin, D.A.; Varlamov, D.A.; Kiseleva, D.V. Platinum-group minerals of Pt-placer deposits associated with the Svetloborsky Ural-Alaskan type massif, Middle Urals, Russia. Minerals 2019, 9, 77. [CrossRef]

5. Zaccarini, F.; Garuti, G.; Pushkarev, E.; Thalhammer, O. Origin of platinum group minerals (PGM) inclusions in chromite deposits of the Urals. Minerals 2018, 8, 379. [CrossRef]

6. Barkov, A.Y.; Shvedov, G.I.; Silyanov, S.A.; Martin, R.F. Mineralogy of platinum-group elements and gold in the ophiolite-related placer of the River Bolshoy Khailyk, Western Sayans, Russia. Minerals 2018, 8, 247. [CrossRef]

7. Nesterenko, G.V.; Zhmodik, S.M.; Belyanin, D.K.; Airiyants, E.V.; Karmanov, N.S. Micrometric inclusions in platinum-group minerals from Gornaya Shoria, Southern Siberia, Russia: Problems and genetic significance. Minerals 2019, 9, 327. [CrossRef]

8. Barkov, A.Y.; Cabri, L.J. Variations of major and minor elements in Pt-Fe alloy minerals: A review and new observations. Minerals 2019, 9, 25. [CrossRef]

9. Yang, S.H.; Su, B.X.; Huang, X.W.; Tang, D.M.; Qin, K.Z.; Bai, Y.; Sakyi, P.A.; Alemayehu, M. Platinum-group mineral occurrences and platinum-group elemental geochemistry of the Xiadong alaskan-type complex in the Southern Central Asian orogenic belt. Minerals 2018, 8, 494. [CrossRef]

10. Koerber, A.J.; Thakurta, J. PGE-enrichment in magnetite-bearing olivine gabbro: New observations from the midcontinent rift-related echo lake intrusion in Northern Michigan, USA. Minerals 2019, 9, 21. [CrossRef]

11. Barkov, A.Y.; Tamura, N.; Shvedov, G.I.; Stan, C.V.; Ma, C.; Winkler, B.; Martin, R.F. Platiniferous tetra-auricupride: A case study from the Bolshoy Khailyk placer deposit, Western Sayans, Russia. Minerals 2019, 9, 160. [CrossRef]

12. Barkov, A.Y.; Shvedov, G.I.; Martin, R.F. PGE-(REE-Ti)-rich micrometer-sized inclusions, mineral associations, compositional variations, and a potential lode source of platinum-group minerals in the Sisim placer zone, Eastern Sayans, Russia. Minerals 2018, 8, 181. [CrossRef]

13. Vymazalová, A.; Laufek, F.; Sluzhenikin, S.F.; Kozlov, V.V.; Stanley, C.J.; Plášil, J.; Zaccarini, F.; Garuti, G.; Bakker, R. Thalhammerite, $\mathrm{Pd}_{9} \mathrm{Ag}_{2} \mathrm{Bi}_{2} \mathrm{~S}_{4}$, a new mineral from the Talnakh and Oktyabrsk deposits, Noril'sk Region, Russia. Minerals 2018, 8, 339. [CrossRef] 